JURNAL PENDIDIKAN, p-ISSN 2715-095X, e-ISSN 2686-5041

Volume 29, No.2, Juli 2020 (151-158)

Online: http://journal. univetbantara. ac. id/index. php/jp

\title{
Peningkatan Prestasi Belajar Alat-alat Optik dengan Kuis Edmodo Peserta Didik Kelas XI MIPA 1 SMA Negeri 1 Gemolong Semester Genap Tahun Pelajaran 2019/2020
}

\begin{abstract}
Parmono
Guru SMA Negeri 1 Gemolong, Sragen, email: parmonogufis@gmail.com

Abstrak: penelitian ini medeskripsikan peningkatan prestasi belajar alat-alat dengan kuis Edmodo peserta didik kelas XI MIPA 1 SMA Negeri 1 Gemolong semester genap tahun pelajaran 2019/2020. Penelitian ini menggunakan dua siklus yaitu siklus I dilaksanakan 2 pertemuan dan siklus II terdiri dari 2 pertemuan. Kuis Edmodo meningkatkan prestasi belajar kompetensi alat-alat optik peserta didik menjadi lebih baik. Hasil prestasi belajar meningkat dari rata-rata 62 menjadi 76. Sedangkan motivasi belajar peserta didik meningkat dari $44 \%$ suka menjadi $64 \%$ suka.
\end{abstract}

Kata-kata Kunci: kuis Edmodo, prestasi belajar, motivasi, dan alat-alat optik

\section{Improving Learning Achievements in Optical Devices with Edmodo Quiz Students of Class XI MIPA 1 of SMA Negeri 1 Gemolong Even Semester Academic Year 2019/2020}

\section{Parmono}

Teacher of SMA Negeri 1 Gemolong, Sragen,email: parmonogufis@gmail.com

\begin{abstract}
This study describes the improvement in learning achievement of tools with Edmodo quiz for grade XI MIPA 1 of SMA Negeri 1 Gemolong second semester of 2019/2020. This study uses two cycles, namely cycle I held 2 meetings and cycle II consisted of 2 meetings. Edmodo Quiz increases student achievement in optical instrument competencies for the better. The results of learning achievement increased from an average of 62 to 76 . While the learning motivation of students increased from $44 \%$ likes to $64 \%$ likes.
\end{abstract}

Keywords: Edmodo quiz, learning achievement, motivation, and optical devices

\section{Pendahuluan}

Setelah WHO mengumumkan virus corona sebagai wabah pandemi maka Mentri Pendidikan dan Kebudayaan membuat edaran seluruh sekolah untuk meliburkan peserta 
didiknya. Termasuk semua proses belajar dilakukan guru dan peserta didik dari rumah. Pembelajaran dengan posisi guru dan peserta didik dari rumah hanya bisa dilakukan dengan moda daring. Banyak aplikasi yang ditawarkan untuk moda daring. Salah satu aplikasi yang dapat digunakan adalah aplikasi Edmodo. Aplikasi Edmodo menyediakan pengelolaan kelas bersama peserta didik, guru, orang tua bahkan dengan pengamat yang lain bisa diundang. Edmodo menyediakan ruang untuk diskusi dengan anggota kelompok atau peserta didik, penugasan dan kuis. Materi alat-alat optik mempunyai kompetensi dasar sebagai berikut: 3.9) menganalisis cara kerja alat optik menggunakan sifat pencerminan dan pembiasan cahaya oleh cermin dan lensa, dan 4.9) menyajikan rancangan/ide sebuah alat optik dengan menerapkan prinsip pemantulan dan pembiasan pada cermin dan lensa. Materi alat-alat optik khususnya mata, mikroskop dan teropong selalu masuk pada SKL soal Ujian Nasional. Pengetahuan tentang mata, mikroskop dan tropong merupakan materi yang kontektual yang sering dialami dan dimiliki oleh peserta didik di dalam kehidupan seharihari. Untuk menganalisa materi tersebut diperlukan pengetahuan matematika yang cukup rumit, sehingga banyak peserta didik yang kesulitan pada kompetensi dasar ini. Kesulitan pada mata, mikroskop dan tropong dialami juga oleh kelas XIMIPA 1 SMA Negeri 1 Gemolong semester genapl tahun pelajaran 2019/2020.

Kesulitan materi pembelajaran ini masih ditambah dengan menggunkan moda daring yang belum pernah digunakan sebelumnya. Pembelajaran daring dengan kuis Edmodo diperlukan beberapa sarana yang mewadai. Sarana tersebut antara lain HP android dengan kuota yang cukup, pengetahuan tentang aplikasi Edmodo dan sinyal yang memadai. Sarana tersebut akan tergantikan dengan kemudahan yang diperoleh guru, peserta didik dan pihak terkait lainnya. Dengan pembelajaran moda daring lewat kuis Edmodoakan membuat peserta didik belajar serasa bermain game. Peserta didik akan termotivasi menjawab game dengan baik yang membuat motivasi peserta didik bertambah besar. Bertambahnya motivasi belajar yang akan berpengaruh pada hasil prestasi belajarnya labih baik. Rumusan masalah penelitian ini sebagai berikut:1) bagaimana peningkatan prestasi belajar alat-alat optik dengankuis Edmodo peserta didik kelas XIMIPA 1SMA Negeri 1 Gemolong semester genap tahun pelajaran 2019/2020,2) bagaimana perubahan motivasi peserta didik kelas XIMIPA 1 SMA Negeri 1 Gemolong semester genap tahun pelajaran 2019/2020, setelah diterapkankuis Edmodo melaui moda daring.

Tujuan penelitiaini adalah sebagai berikut: 1) mendiskripsikan peningkatan prestasi belajar alat-alat optik dengan kuis Edmodo peserta didik kelas XI MIPA 1 SMA Negeri 1 Gemolong semester genap tahun pelajaran 2019/2020, 2) mendeskripsikan perubahan motivasi peserta didik kelas XI MIPA 1 SMA Negeri 1 Gemolong semester genap tahun pelajaran 2019/2020, setelah mendapat pembelajaran moda daring kuis Edmodo. Manfaat penelitian ini memberikan manfaat secara teoretis dan praktis.Secara teoretis penelitianini sebagai inovasi pembelajaran yang dapat digunakan sebagai metode alternatif untuk meningkatkan pembelajaran khususnya pembelajaran kompetensi alat-alat optik. Secara praktis antara lain: 1) bagi peserta didik, hasil penelitian ini dapat bermanfaat untuk meningkatkan motivasi belajar dan kompetensi belajar alat-alat optik peserta didik kelas XI MIPA 1 SMA Negeri 1 Gemolong Semester genap tahun pelajaran 2019/2020, 2) bagi guru, diharapkan hasil penelitian ini dapat meningkatkan kompetensi pedagogis dan kompetensi profesional.

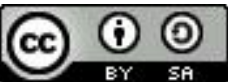




\section{Parmono, Peningkatan Prestasi Belajar Alat-alat Optik dengan Kuis Edmodo ..........}

153

Menurut Winkel (1999:51) prestasi adalah bukti keberhasilan usaha yang dapat dicapai. Prestasi belajar dapat dilihat dari perubahan-perubahan dalam pengertian, pengalaman keterampilan, serta nilai sikap yang bersifat konstan dan berbekas. Perubahan ini dapat berupa sesuatu yang baru atau penyempurnaan sesuatu hal yang telah dimiliki atau dipelajari sebelumnya. Sedangkan menurut Suparno (2007) dalam belajar fisika yang terpenting adalah siswa yang aktif belajar fisika. Setelah belajar peserta didik akan memperoleh prestasi belajar yang bias berbeda beda.Belajar juga merupakan proses mengasimilasikan dan menghubungkan pengalaman atau bahan yang dipelajari dengan pengertian yang sudah dipunyai seseorang sehingga pengertiannya dikembangkan. Proses tersebut antara lain bercirikan sebagai berikut: (1) belajar berarti membentuk makna, makna diciptakan oleh siswa dari yang mereka lihat, dengar, rasakan dan alami; (2) konstruksi arti adalah proses yang terus- menerus, setiap kali berhadapan dengan fenomena atau persoalan yang baru diadakan rekonstruksi, baik secara kuat maupun lemah; (3) belajar bukanlah kegiatan mengumpulkan fakta, melainkan lebih suatu pengembangan pemikiran dengan pengertian yang baru,setelah mendapatkan penemuan dari hasil belajar akan terjadi pengaturan kembali pemikiran seseorang; (4) proses belajar yang sebenarnya terjadi pada waktu skema seseorang dalam keraguan yang merangsang pemikiran lebih lanjut; (5) hasil belajar dipengaruhi oleh pengalaman pelajar dengan dunia fisik dan lingkungannya; (6) hasil belajar seseorang bergantung pada hal-hal yang telah diketahui si pelajar meliputi konsep-konsep, tujuan, kreativitas, dan motivasi.

Sejalan dengan Winkel, Astuti (2018) mengatakan prestasi belajar adalah hasil belajar yang dicapai siswa dalam belajar mengajar. Sedangkan menurut Parmono (2018) prestasi belajar adalah kemampuan yang diperoleh dari proses aktif peserta didik untuk menghubungkan informasi baru dengan kemampuan yang dimiliki sebelumnya. Prestasi belajar terdiri dari tiga domainyaitu domain kognitif, afektif dan psikomotor. Domain kognitif berhubungan dengan kemampuan intelektual. Ada enam tingkatan domain kognitif dari yang sederhana sampai yang lebih kompleks, yaitu: 1) pengetahuan (knowledge; 2) pemahaman (comprehention, understanding); 3) penerapan (application); 4) analisis (analysis; 5) sintesis (synthesis); 6) evaluasi (evaluation). Domain afektif, berhubungan dengan perhatian, sikap, dan nilai. Sedangkan domain psikomotor, meliputi keterampilan motorik dan gerak fisik. Prestasi belajar tidak terlepas dari motivasi belajar. Menurut Robbins, dalam Suprapti Haryani (2019) motivasi mempunyai fungsi yang sangat penting dalam suatu kegiatan, akan mempengaruhi kekuatan dari kegiatan tersebut, tetapi juga dipengaruhi oleh tujuan. Makin tinggi dan berarti suatu tujuan, makin besar motivasinya, dan makin besar motivasi akan makin kuat kegiatan dilaksanakan. Jika peserta didik mempunyai motivasi yang bertambah maka dimungkinkan prestasi belajarnya kan menjadi lebih baik. Dari beberapa teori di atas, dapat disimpulkan bahwa prestasi belajar merupakan hasil yang diperoleh siswa setelah belajar dan mengikuti proses pembelajaran, yang meliputi aspek kognitif, afektif, dan psikomotor. Proses pembelajaran dikatakan berhasil baik apabila dapat menghasilkan prestasi belajar yang baik untuk ketiga domain tersebut.

Menurut Fitri (2019) Edmodo adalah sebuah situs yang diperuntukan bagi pendidik untuk membuat kelas virtual. Situs tersebut gratis dan gampang digunakannya selama seorang guru dan murid bisa terhubung dengan internet. Edmodo merupakan sebuah jawaban bagi sebuah ruang kelas virtual yang nyaman dan aman. Edmodo berupa situs 
microblogging yang dapat digunakan di dalam kelas maupun rumah. Edmodo sendiri bisa diakses melalui mobile dan sudah tersedia untuk smartphone Android dan iPhone. Edmodomerupakan platform pembelajaran berbasis jejaring sosial yang diperuntukan untuk guru, peserta didik sekaligus orang tua peserta didik. Edmodo menyediakan cara mudah untuk membangun kelas virtual berdasarkan pembagian kelas layaknya di sekolah. Edmodo dapat digunakan guru mengirim nilai, tugas, maupun kuis untuk peserta didik dengan mudah. Dalam penggunaan Edmodo perlu diperhatikan kode khusus untuk setiap kelas. Jika peserta didik ingin bergabung pada suatu grup, maka peserta didik terlebih dahulu mengetahui kode khusus grup tersebut. Banyak manfaat Edmodo diantaranya: 1) wahana komunikasi dan diskusi yang sangat efiesien untuk para guru dan peserta didik; 2) peserta didik satu dengan lainnya dapat berinteraksi dan berdiskusi dengan pantauan langsung dari gurunya; 3) mempermudah komunikasi antara guru, peserta didikbahkan orang tua peserta didik; 4) sarana untuk ujian maupun kuis; 5) guru dapat memberikan bahan ajar seperti pertanyaan, foto, video pembelajaran kepada peserta didik.; 6) orang tua peserta didik dapat memantau kegiatan belajar anaknya; 7) mempermudah guru dalam memberikan soal dari mana saja dan kapan saja. Dari beberapa keterangan tersebut diatas dapat dikatakan bahwa kuis Edmodo adalah platform pembelajaran berbasis jejaring sosial yang diperuntukan untuk guru, peserta didik sekaligus orang tua peserta didik yang berupa tugas, penilaian, diskusi,pemberian bahan ajar dengan menitik beratkan pada pemberian kuis.

Berdasarkan silabus fisika tahun 2013 kompetensi alat-alat optik mempunyai kompetensi inti sikap menghayati dan mengamalkan perilaku jujur, disiplin, tanggungjawab, peduli (gotong royong, kerjasama, toleran, damai), santun, responsif dan pro-aktif dan menunjukkan sikap sebagai bagian dari solusi atas berbagai permasalahan dalam berinteraksi secara efektif dengan lingkungan sosial dan alam serta dalam menempatkan diri sebagai cerminan bangsa dalam pergaulan dunia. Kompetensi pengetahuan memahami, menerapkan, dan menganalisis pengetahuan faktual, konseptual, prosedural, dan metakognitif berdasarkan rasa ingin tahunya tentang ilmu pengetahuan, teknologi, seni, budaya, dan humaniora dengan wawasan kemanusiaan, kebangsaan, kenegaraan, dan peradaban terkait penyebab fenomena dan kejadian, serta menerapkan pengetahuan prosedural pada bidang kajian yang spesifik sesuai dengan bakat dan minatnya untuk memecahkan masalah.. Pembelajaran alat-alat optik menurut silabus terdiri dari:1) menjelaskan pengertian alat-alat optik; 2) menjelaskan fungsi dan cara kerja alat-alat optik; 3) menggambarkan pembentukan bayangan benda pada retina; 3) menjelaskan pengertian titik dekat, titik jauh dan akomodasi mata; 4) menjelaskan beberapa cacat mata dan cara penanggulangannya menggunakan kacamata; 5) membedakan pengamatan tanpa akomodasi dengan berakomodasi maksimum pada alat optik lup, mikroskop dan teropong; 6) melakukan percobaan pembentukan bayangan pada beberapa alat optik; 7) menganalisis tentang pembentukan bayangan dan perbesaran pada kaca mata, lup, mikroskop dan teropong

Materi alat-alat optik merupakan materi yang perlu mendapat perhatian mengingat materi ini selalu keluar dalam soal ujian nasional.Kuis Edmododilaksanakandengan mengemas pembelajaran moda daring melali aplikasi Edmodo.Pada pembelajaran dimana guru dan peserta didik berada di rumah yang sesuai dengan pengarahan pemerintah untuk belajar dari rumah dalam rangka menghidari wabah covid-19. Semua kegiatan dari rumah 


\section{Parmono, Peningkatan Prestasi Belajar Alat-alat Optik dengan Kuis Edmodo ......... 155}

lewat HP antau laptop masing-masing dengan bantuan aplikasi Edmodo. Dengan mengerjakan kuis Edmodo peserta didik akan belajar serasa bermain. Kegiatan belajar bermain ini secara langsung akan membuat peserta didik senang. Perasaan senang ini akan menimbulkan motivasi belajar walaupun harus belajar melalui daring dari rumah. Kesenangan dan motivasi inilah yang akan mempengaruhi prestasi belajar emnajadi lebih baik.

Hipotesis tindakan penelitian ini terdiri dari: 1) dengan menerapkan pembelajaran dengan kuis Edmodo secara optimal, prestasi belajar kompetensi alat-alat optik peserta didikkelas XI MIPA 1SMA Negeri 1 Gemolong semester genap Tahun Pelajaran 2019/2020akan meningkat; 2) dengan menerapkan pembelajaran kuis Edmodo secara optimal, motivasi peserta didik kelas MIPA 1SMA Negeri 1 Gemolong semester genap Tahun Pelajaran 2019/2020 meningkat.

\section{Metode Penelitian}

Penelitian ini merupakan penelitian tindakan kelas yang menekankan pada tindakan komponen proses pembelajaran dalam upaya menyelesaikan masalah yang timbul pada saat pembelajaran. Komponen proses pembelajaran terdiri dari perencanaan, tindakan, pengamatan, dan refleksi. Dalam satu proses ke empat komponen tersebut dinamakan satu siklus. Proses usaha perbaikan empat komponen pembelajaran pertama atau yang disebut siklus I dilakukan untuk perbaikan proses pembelajaran berikutnya. Siklus II yang merupakan proses pembelajaran yang dilakukan tindakan dengan acuan refleksi dari siklus I. Perencanaan dimulai dari menyusun jadwal penelitian, pembuatan akun di aplikasi baik guru maupun peserta didik sampai terbentuk kelas Edmodo sampai dengan input kuis Edmodo pada aplikasi. Setelah penyusunan kuis selesai maka langkah selanjutnya menugaskan kelas dengan batasan waktu yang diinginkan. Kegiatan ini dilakukan pada bulan maret 2020. Tindakan proses pembelajaran dilakukan dengan daring. Guru berada di rumah sedangkan peserta didik berada ditempat lain sesuai kondisinya dengan jam ditentukan. Peserta didik mengakses aplikasi Edmodo dengan kode akses yang telah diberikan oleh guru. Selanjunya peserta didik akan asik mengerjakan kuis sehingga pembelajaran ini tidak menjemukan.

Pengamatan dilakukan oleh guru yang selalu memonitor kegiatan peserta didik dari jarak jauh memakai aplikasi Edmodo. Pada aplikasi Edmodo akan diperoleh hasil dari pekerjaan peserta didik yang sudah diringkas dalam bentuk diagram. Hasilnya kuis juga bias dilihat oleh peserta didik, dan guru. Setelah kuis dikerjakan guru mengamati hasilnya selanjutnya melakukan refleksi dari tindakan yang berguna untuk pembelajaran berikutnya. Penilaian dalam indikator data kualitatif dilakukan berdasarkan teknik tes. Data tersebut diambil dari hasil penilaian melalui bentuk kuis pada aplikasi Edmodo. Dari hasil olah data, peserta didik dapat dinyatakan berhasil, jika nilai peserta didik mencapai kompetensi ketuntasan minimal (KKM). KKM pada kompetensi alat-alat optik sebesar 75. Dengan kata lain peserta didik yang dinyatakan tuntas jika memperoleh nilai minimal 75.

\section{Hasil Penelitian dan Pembahasan}


Pada siklus I dapat ditampilkan hasil penelitian berupa ringkasan pada aplikasi Edmodo sebagai berikut:

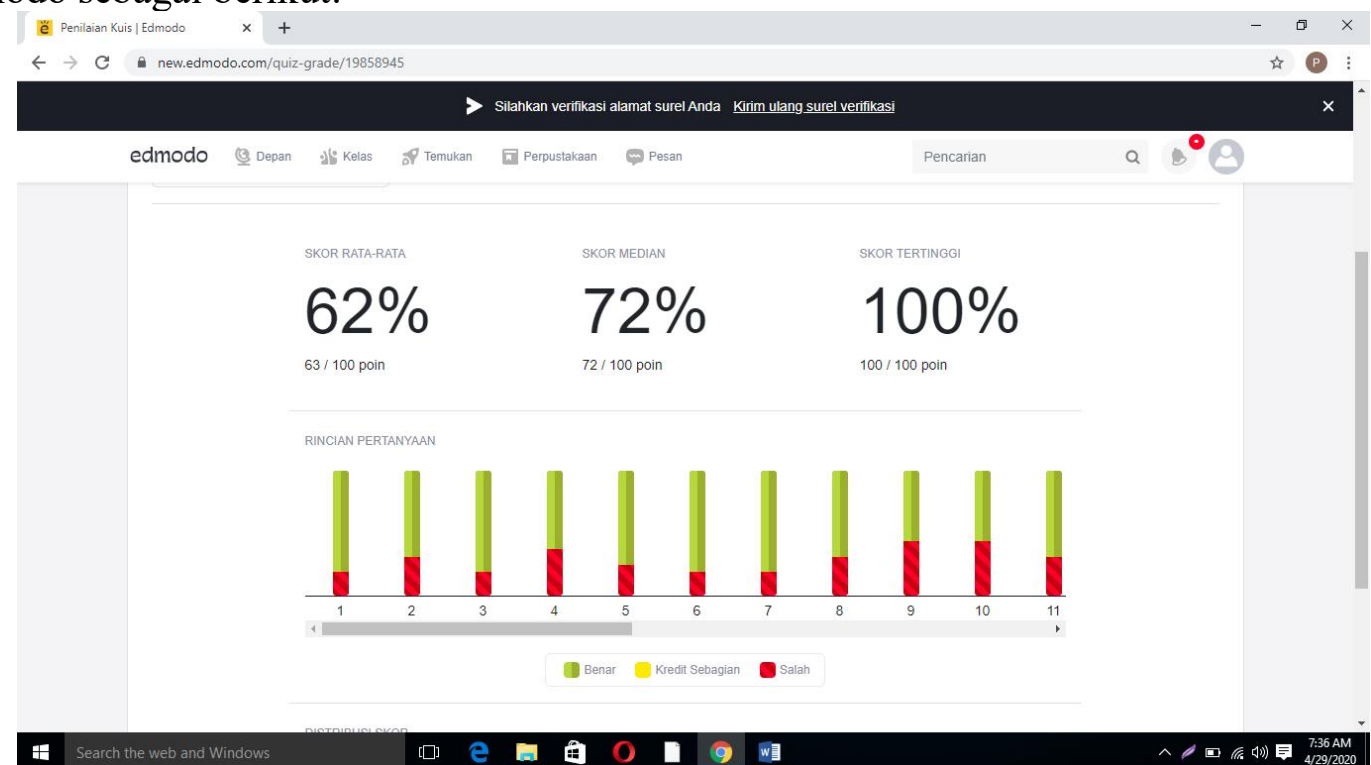

Gambar 1. Diagram Ringkasan Prestasi Belajar Hasil Penelitian Siklus I

Dari diagram tersebut diperoleh rata-rata prestasi belajar peserta didik pada siklus I sebesar $62 \%$ atau dengan nilai 62. Nilai tengah 72 dan tertinggi 100. Selain berupa ringkasan pada aplikasi Edmodo ada fasilitas juga hasil dalam bentuk nilai perindividu. Dari data peserta didik perindividu diperoleh peserta didik tuntas sebanyak 22 dan 14 peserta didik belum memenuhi kriteria ketuntasan minimum (KKM). Dari 14 peserta didik yang belum tuntas ini bahkan ada yang memperoleh nilai dibwah 50. Setiap peserta didik disuruh untuk menuliskan tanggapan pada pembelajaran ini yang hasilnya dari 36 peserta didik ada 16 menunjukan suka dengan pembelajaran ini.Tanggapan peserta didik yang suka terhadap pembelajaran ini dapat dipakai sebagai acuan bahwa terdapat motivasi peserta didik pada pembelajaran daring ini. Hasil pada siklus I diamati dan dianalisa sebagai bentuk refleksi siklus I.

Dari analisa hasil refleksi pada siklus I diperoleh kelemahan pada kesiapan peserta didik menggunakan moda daring yang baru diterapkan menggunakan aplikasi Edmodo dan kesiapan sarana peserta didik yang belum maksimal. Pada siklus II dilakukan perbaikan diantaranya peserta didik didik untuk membiasakan diri dengan aplikasi Edmodo dengan handphone masing-masing. Memperbaiki akun bila perlu dan yang terpenting menyiapkan tempat belajar dengan koneksi internet yang memadai. Hasil penelitian pada siklus II dapat dilihat pada gambar 2 sebagai berikut . 


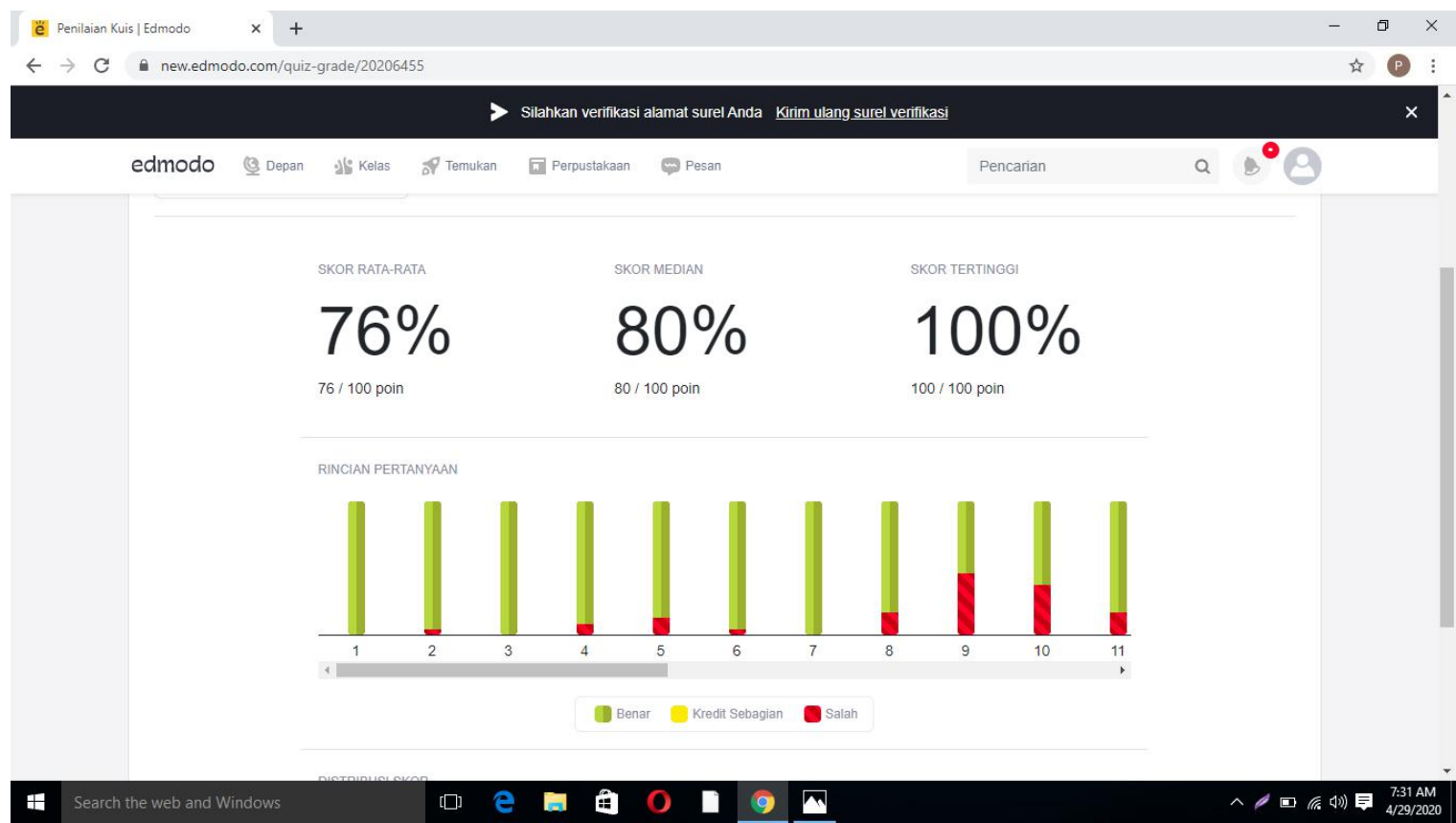

Gambar 2. Diagram Ringkasan Prestasi Belajar Hasil Penelitian Siklus II.

Dari diagram tersebut diperoleh rata-rata prestasi belajar peserta didik pada siklus II sebesar 76\% atau dengan nilai 76. Nilai tengah 80 dan tertinggi 100. Dari data lain diperoleh siswa yang menunjukan peningkatan dengan menuliskan like pada tanggapan sebanyak 23 peserta didik. Dari jumlah 36 peserta didik terdapat 30 peserta didik yang memperoleh nilai diatas KKM sedangkan 6 peserta didik memperoleh nilai dibawah KKM.

Dengan demikian pada siklus II terdapat 30 peserta didik tuntas dan 6 peserta didik yang belum tuntas. Sesuai data diatas diperoleh hasil adanya peningkatan prestasi belajar peserta didik rata-rata dari nilai 62 menjadi 76. Jika dilihat dari nilai KKM sebesar 75 maka dapat dikatakan prestasi belajar peserta didik pada kompetensi alat-alat optik rata-rata meningkat dari nilai belum tuntas menjadi sudah tuntas. Dilihat dari jumlah peserta didik yang tuntas terdapat peningkatan dari 22 menjadi 30 peserta didik mencapai kriteria ketuntasan minimum.Sedangkan jika dilihat dari motivasi peserta didik dari yang menanggapi suka dari $44 \%$ suka menjadi $64 \%$ suka. Terdapat peningkatan motivasi sebesar $20 \%$.

\section{Simpulan dan Saran}

Dari hasil penelitian dan pembahasan diatas dapat disimpulkan bahwa: 1) kuis Edmodo dapat meningkatkan prestasi belajar alat-alat optik peserta didik kelas XI MIPA 1 SMA Negeri 1 Gemolong semester genap tahun pelajaran 2019/2020; 2)Kuis Edmodo meningkatkan motivasi belajar alat-alat optik peserta didik kelas XI MIPA 1 semester genap tahun pelajaran 2019/2020.

Berdasarkan hasil penelitian ini maka disampaikan saran sebagai berikut : 1) bagi peserta didik saat menggunakan aplikasi kuis Edmodo untuk dapat memperhatikan betul 
sarana HP dan koneksi internet dengan baik. 2) bagi kuis Edmodo dapat menjadi pembelajaran moda daring alternatif dengan fasilitas fitur yang memadai.

\section{Daftar Rujukan}

Parmono. (2018). Optimalisasi Ariasmuda untuk Meningkatkan Kompetensi Belajar Fluida Statik Kelas XI MIPA 3 SMA Negeri 1 Gemolong Tahun Pelajaran 2016/2017. Jurnal Pendidikan. Volume 27 Nomor 3 , November 2018. Hal:305-314.

Rintang Puji Astuti. (2018). Peningkatan Prestasi Bahasa Inggris dengan Penerapan Model Pembelajaran KooperatifTipe Thing Pair Share (TPS) Pada Siswa Kelas VII A SMP Negeri 2 Sukoharjo Semester II Tahun Pelajaran 2015/2016. Jurnal Pendidikan, Volume 27 Nomor 3 , November 2018. Hal:333-344.

Suparno, Paul. (2007). Metodologi Pembelajaran Fisika Konstruktivistik dan Menyenangkan. Yogyakarta: Universitas Sanata Darma

Suprapti Hariyani. (2019). Peningkatan Aktivitas dan Hasil Belajar IPA Materi Sistem Ekresi Manusia Melalui Model Pembelajaran Discovery Learning dan Metode Eksperimen Siswa Kelas VIII G SMP Negeri 1 Boyolali pada Semester Genap Tahun Pelajaran 2018-2019. Jurnal Pendidikan, Volume 28 Nomor 3 , 2019. Hal:339-352.

Triman. (2017). Upaya Meningkatkan Hasil Belajar Penjasorkes melalui Permainan Kasbol pada Siswa Kelas IV SD N Bulakrejo 01 Kecamatan Sukoharjo Kabupaten Sukoharjo Tahun Pelajaran 2016/2017. Jurnal Pendidikan, Volume 26 Nomor 2. Juli 2017. Hal:215-224.

Winkel, W. S. (1996). Psikologi Pengajaran. Jakarta: Grasindo.

Yeni Fitri. (2014). Makalah Edmodo. Diambil dari: http://yenifitri20.blogspot.com/ 2014/01/v-behaviorurldefaultvmlo.html 